\title{
RELATED FACTORS WITH BREAST CANCER CASES IN WOMEN AT ULIN HOSPITAL BANJARMASIN
}

\author{
Elvine Ivana Kabuhung ${ }^{1 *}$ \\ ${ }^{1}$ Sari Mulia School of Health Science, Banjarmasin, Indonesia \\ *Elvine_ivana_kabuhung@stikessarimulia.ac.id \\ Eka Sapitri ${ }^{1}$, \\ ${ }^{1}$ Sari Mulia School of Health Science, Banjarmasin, Indonesia \\ Eka_safitri@gmail.com
}

Fadhiyah Noor Anisa ${ }^{2}$

${ }^{2}$ Midwifery Academy Sari Mulia Banjarmasin

Fadhiya_noor_annisa@akbidsarimulia.ac.id

\begin{abstract}
Objective: To analyze factors related to the incidence of breast cancer in women at Ulin Hospital Banjarmasin.

Research Method: The design of case-control research with ratio 1: 1. Sampling by systematic random sampling. As many as 45 people breast cancer and 45 people do not suffer from breast cancer. Data analysis using Chi-square test.

Results: Case with the age of $\geq 40$ years 41 people $(91.11 \%)$, and Obese 35 people $(77,78 \%)$ cause breast cancer in women. Control of age $\geq 40$ years 8 persons $(17.78 \%)$, and obese 15 persons $(33.33 \%)$. There is a relation between woman age $(\mathrm{p}=0,000)<0,05$ with $\mathrm{OR}=0,021$. There is a relationship between female obesity $(\mathrm{p}=0,000)<0.05$ with $\mathrm{OR}=7,000$.

Conclusion: Women aged $\geq 40$ years are at risk 0.021 times more likely to develop breast cancer than $<40$ years of age, and women with obesity are 7,000 times more likely to develop breast cancer than those who are not obese.
\end{abstract}

Keywords: Age, Breast Cancer, Case Control, Obesity.

\section{INTRODUCTION}

Cancer is one of the diseases included in the group of non-communicable diseases (NCD). NCD is the biggest cause of death in the world. Of the 57 million deaths in 2008, 63\% (36 million deaths) were caused by $\mathrm{NCD}$, mainly due to cardiovascular disease with 17 million deaths, 7.6 million cancer deaths, chronic lung disease of 4.2 million deaths and illness diabetes by 1.3 million deaths. About a quarter of the world's NCD deaths occur at the age of 60 years. The mortality rate due to NCD is higher than the total number of deaths due to other causes. Contrary to popular opinion, $80 \%$ of NCD deaths occur in low- and middle-income countries. NCD is the highest cause of death in most countries in America, the Eastern Mediterranean, Europe, Southeast Asia and the Western Pacific [1] 
In the next decade, cancer is predicted as an increasingly important cause of illness and death worldwide. The challenge for cancer control is enormous, coupled with population characteristics with increasing age. Therefore, increased prevalence of cancer is difficult to avoid. It is estimated that in 2008 there were 12.7 million new cases of cancer, and this number is predicted to be 21.4 million cases by 2030. Two-thirds of those cases are found in countries with low-medium socioeconomic [1].

WHO 2015, revealed that more than $30 \%$ of cancer deaths can be prevented by modifying or avoiding major risk factors for which one is overweight or obese. Obesity is derived from other behavioral factors/factors that become risk factors for breast cancer.

Kemenkes 2015 [2] said that most cancer diseases in Dharmais Cancer Hospital for 4 consecutive years are breast, cervical, lung, ovarian, rectal, thyroid, colon, hepatoma, and nasopharyngeal cancer. NonHodgkin lymphoma cancer is ranked 10th most cancer in 2010 and 2011, but in 2012 and 2013 the 10th most cancer is soft tissue cancer. During the years 2010-2013, breast cancer, cervical cancer and breast cancer are the three most common diseases in the Dharmais Cancer Hospital, and the number of new cases and the number of deaths from cancer continues to increase. In Indonesia, there is no accurate statistical data, but data collected from hospitals showed that breast cancer ranked first among other cancers in women. Each year, in the United States 44,000 patients die from the disease while in Europe more than 165,000. After treatment, about $50 \%$ of patients have end-stage breast cancer and only survive 18-30 months [3] Until now generally the cause of the growth of breast cancer cannot be known with certainty, but there are several factors that are expected to trigger the onset of this cancer. Factors such as age, because people affected by breast cancer is estimated at about $60 \%$ under the age of 50 years. Another cause is the possibility among other family members who have had breast cancer, so the disease is most likely about the woman in question. Genetic factors (heredity) and hormonal conditions can also be regarded as the cause of the growth of this cancer in a woman. This hormonal factor is considered quite important because this hormone can trigger the growth of breast cancer in women concerned. This disease may also be contagious in people who have participated by taking birth control pills and post-menopause [4]

Currently, non-infectious diseases, including cancer, become major health problems both in the world and in Indonesia. According to WHO data in 2013, the incidence of cancer increased from 12.7 million cases in 2008 to 14.1 million cases in 2012. While the number of deaths increased from 7.6 million people in 2008 to 8.2 million in 2012. Cancer causes death number 2 in the world by $13 \%$ after cardiovascular disease. It is estimated that in 2030 the incidence of 
cancer can reach 26 million people and 17 million of them died from cancer, especially for poor countries and progress will happen faster

Research conducted by Sri Wahyuni, et al at RSUD Semarang City in 2015 [5] stated that obesity has value Odds Ratio equal to 2,536 which means increased risk factor for breast cancer compared to a woman who is not obesity.

Research conducted by Ulya Qaulan Karima, et al in dr. Cipto Mangunkusumo Jakarta in 2013 stated that the age of $\geq 40$ years has a value of Odds Ratio 3,690 which means age $\geq 40$ years increase the risk of breast cancer compared to age $<40$ years.

Based on the preliminary study conducted in the chemotherapy room of RSUD Ulin Banjarmasin, women suffering from breast cancer amounted to 488 people in 2014, to 558 people in 2015, and to be 957 people in 2016 women suffering from breast cancer.

Based on the above data, the researchers are interested to conduct a research on "Factors related to the incidence of breast cancer in women at Ulin Hospital Banjarmasin".

\section{RESEARCH METHOD}

This research was conducted in RSUD Ulin Banjarmasin. The research method used an analytical survey based on case-control approach. The population in this study were all women suffering from breast cancer in
Edelwis Room amounted to 957 people. The number of samples in this study was 90 people, 45 cases, and 45 controls. The number of samples is obtained by using solving formula.

The sampling technique used is systematic random sampling withdraw method.

\section{RESULTS}

1. Univariate Analysis

a. Age

Table 1 Distribution of Frequency of Patient Age at Ulin hospital Banjarmasin

\begin{tabular}{lcccc}
\hline \multirow{1}{*}{ Age } & \multicolumn{2}{c}{$\begin{array}{c}\text { Cases (Breast } \\
\text { cancer) }\end{array}$} & \multicolumn{2}{c}{$\begin{array}{c}\text { Control (No } \\
\text { breast cancer) }\end{array}$} \\
\cline { 2 - 5 } & Jumlah & $\%$ & Jumlah & $\%$ \\
\hline $\begin{array}{l}\text { At risk } \geq 40 \\
\text { years }\end{array}$ & 41 & 91,11 & 8 & 17,78 \\
\hline $\begin{array}{l}\text { Not at risk } \\
<40 \text { years }\end{array}$ & 4 & 8,89 & 37 & 82,22 \\
\hline Total & 45 & 100 & 45 & 100 \\
\hline
\end{tabular}

Table 1 shows the frequency distribution of patient's age at RSUD Ulin Banjarmasin. In the case age group not at risk $<40$ years consisting of 4 people $(8.89 \%)$ had breast cancer and in the age control group no risk $<40$ years consisting of 37 people $(82.22 \%)$ did not have breast cancer.

b. Obesity

Table 2 Distribution of Obesity Patients Frequency.

\begin{tabular}{|c|c|c|c|c|}
\hline \multirow{2}{*}{ Obesity } & \multicolumn{2}{|c|}{$\begin{array}{c}\text { Cases (Breast } \\
\text { cancer) }\end{array}$} & \multicolumn{2}{|c|}{$\begin{array}{c}\text { Control (No } \\
\text { breast cancer) }\end{array}$} \\
\hline & $\begin{array}{c}\text { Numb } \\
\text { er }\end{array}$ & $\%$ & Number & $\%$ \\
\hline $\begin{array}{l}\text { With } \\
\text { obesity }\end{array}$ & 35 & 77,78 & 15 & 33,33 \\
\hline $\begin{array}{l}\text { No } \\
\text { Obesity }\end{array}$ & 10 & 22,22 & 30 & 66,67 \\
\hline Total & 45 & 100 & 45 & 100 \\
\hline Table & 2 & WS & he & obesi \\
\hline
\end{tabular}

frequency distribution in RSUD Ulin

Banjarmasin. In the non obese group the case 
consisted of 3 people with BMI $\geq 18,5-<24.9$ Classification Normal, and 7 people with BMI $\geq 25$ - <27 Classification Overweight, while in the non-obese group control of 12 people with IMT $\geq 18,5-<24,9$ Classification Normal, 18 people with IMT $\geq 25-<27$ Classification Weight Loss.

\section{Bivariate Analysis}

a. Age Relationship with Breast Cancer Incidence

Table 3 Relationship Age with Breast Cancer Incidence In Women.

\begin{tabular}{|c|c|c|c|c|c|c|}
\hline \multirow[t]{2}{*}{ Usia } & \multicolumn{2}{|c|}{$\begin{array}{l}\text { Cases } \\
\text { (breast } \\
\text { cancer) }\end{array}$} & \multicolumn{2}{|c|}{$\begin{array}{c}\text { Control (No } \\
\text { breast } \\
\text { cancer) }\end{array}$} & \multicolumn{2}{|c|}{ Total } \\
\hline & $\mathrm{F}$ & $\%$ & $\mathrm{~F}$ & $\%$ & $\mathrm{~F}$ & $\%$ \\
\hline $\begin{array}{l}\text { At risk } \geq 40 \\
\text { years }\end{array}$ & 41 & 91,11 & 8 & 17,78 & 49 & 54,44 \\
\hline $\begin{array}{l}\text { Not at risk } \\
<40 \text { years }\end{array}$ & 4 & 8,89 & 37 & 82,22 & 41 & 45,56 \\
\hline Total & 45 & 100 & 45 & 100 & 90 & 100 \\
\hline Chi-Square & \multicolumn{6}{|c|}{$P=0,000$} \\
\hline Odds Ratio & \multicolumn{6}{|c|}{$O R=0,021(0,006-0,076)$} \\
\hline
\end{tabular}

breast cancer incidence in $\geq 40$ years old women as many as 41 people (91.11\%), whereas women who did not have breast cancer 37 people $(82.22 \%)$ were included at no risk $<40$ years. While women who have breast cancer age are not at risk $<40$ years 4 people $(8.89 \%)$ due to other causes that cause the person affected by breast cancer such as hereditary history, the use of hormonal contraception, early menarche, and others.

Chi-Square test result is $p=0,000$ then $p$ $<\alpha(0,05)$, so the result of the hypothesis is $\mathrm{H} 1$ accepted, meaning there is a relation of age of a woman with the incidence of breast cancer at Ulin Banjarmasin Hospital. OR (Odds
Ratio) value is 0,021 meaning age at risk $\geq 40$ years has a 0.021 times greater likelihood of developing breast cancer compared to age not at $<40$ years of age.

b. Relationship Obesity with Breast Cancer Incidence

Table 4 Relationship Age with Breast Cancer Incidence In Women.

\begin{tabular}{|c|c|c|c|c|c|c|}
\hline \multirow[t]{2}{*}{ Obesity } & \multicolumn{2}{|c|}{$\begin{array}{l}\text { Cases } \\
\text { (Breast } \\
\text { cancer) }\end{array}$} & \multicolumn{2}{|c|}{$\begin{array}{c}\text { Control (No } \\
\text { breast } \\
\text { cancer) }\end{array}$} & \multicolumn{2}{|c|}{ Total } \\
\hline & $\mathrm{F}$ & $\%$ & $\mathrm{~F}$ & $\%$ & $\mathrm{~F}$ & $\%$ \\
\hline $\begin{array}{l}\text { With } \\
\text { Obesity }\end{array}$ & 35 & 77,78 & 15 & 33,33 & 50 & 55,56 \\
\hline No Obesity & 10 & 22,22 & 30 & 66,67 & 40 & 44,44 \\
\hline Total & 45 & 100 & 45 & 100 & 45 & 100 \\
\hline Chi-Square & \multicolumn{6}{|c|}{$P=0,000$} \\
\hline Odds Ratio & \multicolumn{6}{|c|}{$O R=7,000(2,742-17,867)$} \\
\hline
\end{tabular}

Based on Table 4 shows that obesity factor is related to breast cancer, case group as many as 35 people $(77,78 \%)$ woman included in the group of obesity, while control group counted 30 people $(66,67 \%)$ not obese including women group which is not at risk exposed to breast cancer. While from the case group there are 10 people (22.22\%) women are not obese but have breast cancer caused by other factors that are family history, not breastfeeding, alcohol consumption, and others.

Chi-Square test result is $p=0,000$ then $\mathrm{p}<\alpha(0,05)$, so hypothesis hassle $\mathrm{H} 1$ is accepted, meaning there is a relationship of obesity with the incidence of breast cancer in a woman at Ulin Hospital Banjarmasin. OR value (Odd Ratio) 7,000 means obesity is 7,000 times more likely to develop breast cancer than women who are not obese. 
Based on the results of calculations from the data samples of research results, obtained the results of breast cancer incidence as many as 45 people who suffer from breast cancer. Women aged at risk ( $\geq 40$ years) of 41 people $(91.11 \%)$ with age $40-50$ years were $15(33.33 \%)$ and age> 50-60 were 19 $(42.22 \%)$ and age $>60$ years amounted to 7 people $(15.55 \%)$. While women with obesity as many as 35 people $(77.78 \%)$ with IMT $27-$ 30 amounted to 30 people $(68.89 \%)$ and IMT> 30 amounted to 5 people $(11.11 \%)$.

Risk factors associated with breast cancer incidence in women at risk of 0.021 mean age $(\geq 40)$ years at 0.021 times greater risk of developing breast cancer compared with age, not at risk ( $<40$ years). Women at risk 7,000 times mean obesity is 7,000 times greater risk of developing breast cancer compared with non-obese at Ulin Hospital Banjarmasin.

\section{DISCUSSION}

1. Univariate Analysis

a. Age

From the results of the study, it was found that in the case group are not at risk $<40$ years old consisting of 4 people $(8,89 \%)$ had breast cancer and in age control group not at risk $<40$ years consist of 37 people $(82,22 \%)$ did not have breast cancer.

Based on these results women who suffer from breast cancer lies in the productive age but its development occurs in old age and gradually.
The risk of breast cancer increases with age because of the effects of long exposure to hormonal (estrogen) and exposure to other risk factors that take a long time to induce the occurrence of breast cancer. Some breast cancers occur in women with age range $>40$ years. That's because at that age there is a decline in the function of organs so that in old age sicker including breast cancer.

b. Obesity

Obesity is an increase in body weight over the limit in the body. Obesity is a condition that shows an imbalance between height and weight due to fat tissue in the body so that there is the excess weight that exceeds the ideal size.

Obesity has a stimulating effect on the development of breast cancer. Estrogen is stored in the adipose tissue. Some breast cancer is a positive estrogen receptor meaning that estrogen stimulates the growth of breast cancer cells. Then the more adipose tissue, the more estrogen that binds the cancer cells.

Fatty tissue is a major place in endogenous estrogen production. Therefore, women with more weight than high BMI have higher estrogen levels.

\section{Bivariate Analysis}

a. Correlation of Age and Breast Cancer Cases

Breast cancer is a malignant tumor that grows in the breast tissue. It can be inside the mammary glands, fat tissue or in the connective tissue contained in the breast [6] 
Factors associated with the occurrence of breast cancer in women including age $>40$ years are at great risk, genetic (hereditary), use of drugs (hormone replacement HRT (hormone replacement therapy) such as estrogen hormone), unmarried, 35 years old, not breastfeeding, stress, early menarche, menopause at an advanced age, a history of benign breast, obesity, and use of oral contraceptives in women [3]

According to the results of research conducted by Ulya Qaulan Karima, et al in 2013 found that women who have age $\geq 40$ years have a chance of 3,690 times will suffer from breast cancer. In the study explained that there is a significant relationship between age with the incidence of breast cancer in women related to menopausal age.

Based on age it was found that 45 women who had breast cancer are at risk $\geq 40$ years counted 41 people $(91,11 \%)$. The risk of breast cancer increases with age because of the effects of long exposure to hormonal (estrogen) and exposure to other risk factors that take a long time to be able to induce the occurrence of breast cancer. Most breast cancer after menopause and about $75 \%$ of cases of breast cancer occur after the age of 50 years.

This is in accordance with the theory according to Suryaningsih (2009), women aged $>40$ years have a greater risk of breast cancer than age $<40$ years. Hal this is because at age $<40$ years most women do realize (selfexamination breast) at home routinely, mammography, or ultrasound at a local breast examination program (Lincoln, 2008).

Like other diseases, the risk of breast cancer increases with age. The longer a person's age, the possibility of genetic damage (mutation) is also increasing. On the other hand, the ability to repair the body (healing) decreases further. In the age range 30-39 years, the risk of cancer is 1 in 233 people or about $0.43 \%$. When a woman reaches her $60 \mathrm{~s}$, the risk will jump to 1 in 27 people or nearly $4 \%[7]$

However, based on table 4.3 it can also be seen that women who have breast cancer but are not included in the risk-age group as many as 4 people $(8.89 \%)$, meaning that although the mother is not included in the age group at risk, there is still the possibility of the mother will have cancer breast due to other factors such as early menarche, family history, alcohol consumption, not breastfeeding, the use of hormonal contraceptives and others.

b. Correlation of Obesity and Breast Cancer Cases

Obesity is a condition that shows an imbalance between height and weight due to fat tissue in the body so that there is the excess weight that exceeds the ideal size .Obesity is one of the factors causing the occurrence of breast cancer in women.

According to research conducted by Sri Wahyuni, et al 2015 found that women who are obese have a 2.536 times risk of breast cancer compared with women who are not obese. In this study clearly, there is a 
relationship between obesity with the incidence of breast cancer in women.

Based on obesity, it was found that of 45 women with obesity (IMT $\geq 27$ ), 35 $(77.78 \%)$ were at risk. Obesity has a triggering effect on the development of breast cancer. Estrogen is stored in adipose tissue (fat tissue). Some breast cancers are estrogen receptor positive $(\mathrm{ER}+)$, meaning that estrogen encourages the growth of breast cancer cells. Thus, the more adipose tissue, the more estrogen that binds $(\mathrm{ER}+)$ cancer cells. Fatty tissue is a major site in the reproduction of endogenous estrogens. Therefore, women with more weight than the Body Mass Index (BMI) are high, have a high estrogen level. Maintaining a Body Age Index (BMI) of $20-25 \mathrm{~kg} / \mathrm{m} 2$ will reduce the risk of breast cancer

This suggests that obesity is one of the factors causing breast cancer incidence. Breast cancer risk factors are almost entirely directly or indirectly associated with unused estrogen and remaining in the body or estrogen that is not matched by progesterone [3].

Being overweight or obese after menopause increases the risk of breast cancer. Before menopause, the female ovaries produce most of the estrogen. After menopause (when the ovaries stop making estrogen), most of the female estrogen comes from fat tissue. Having more fat tissue after menopause can increase the risk of breast cancer with high estrogen [8].
Based on table 4.4 can be seen that from the case of women not obese as much as $10(22.22 \%)$ have breast cancer. It is possible that there are other variables that may cause women to develop breast cancer other than obesity, one of them being age, family history of breast cancer, oral contraceptives, first pregnancy> 35 years etc. From the research conducted, researchers found that most women who suffer from breast cancer are not included in the group of obese are at risk, but the woman has another factor that is sex. Therefore, to assess whether the factors that affect the incidence of breast cancer is not seen from one factor alone but also from many factors so that early detection of breast cancer causing factors that occur in women.

\section{REFERENCES}

[1]. WHO. 2010. Non-Communicable Diseases. World Health Organization.

[2]. Departemen kesehatan RI. 2015. Riset Kesehatan Dasar : Riskesdas 2015

[3]. Mulyani, Sri Nina dan Nuryani. 2013. Kanker Payudara dan PMS Pada Kehamilan. Yogyakarta: Nuha Medika.

[4]. Saydam G. Syafni. 2014. Waspadai Penyakit Reproduksi Anda. Jakarta: Pustaka Reka Cipta.

[5]. Sri Wahyuni, dkk. 2015. Hubungan Obesitas dengan Kejadian Kanker Payudara di RSUD Kota Semarang.

[6]. Supriyanto, Wawan. 2010. Ancaman Penyakit Kanker Deteksi Dini \& Pengobatannya. Jogjakarta: Cahaya Ilmu.

[7]. Handayani, dkk. 2012. Menaklukan Kanker Serviks dan Kanker Payudara 
dengan Terapi Alami. Jakarta: Agro Media Pustaka.

[8]. ACS. 2013. Breast Cancer. downloaded, 2017, May 9 , from www.cancer.org/ 